\title{
HUBUNGAN PERANAN WANITA TANI DALAM BUDIDAYA PADI SAWAH \\ DENGAN PENERAPAN TEKNOLOGI PENGELOLAAN TANAMAN TERPADU (PTT)
}

(Suatu Kasus di Desa Wanareja Kecamatan Wanareja Kabupaten Cilacap)

\author{
Oleh: \\ Eni Edniyanti ${ }^{1}$, Dedi Herdiansah $\mathbf{S}^{2}$, Sudradjat $^{3}$ \\ 1) Mahasiswa Fakultas Pertanian Universitas Galuh \\ 2) Dosen Fakultas Pertanian Universitas Galuh \\ 3) Dosen Fakultas Pertanian Universitas Galuh
}

\begin{abstract}
ABSTRAK
Penelitian ini bertujuan untuk mengetahui: 1) Tingkat Peranan wanita dalam budidaya padi sawah, 2) Tingkat penerapan teknologi pengelolaan tanaman terpadu padi sawah dan 3) Hubungan peranan wanita dalam budidaya padi sawah dengan penerapan teknologi pengelolaan tanaman terpadu padi sawah. Metode yang digunakan dalam penelitian ini adalah metode survai. Subjek penelitian adalah wanita tani yang pernah mengikuti kegiatan SL-PTT Padi Sawah di Desa Wanareja Kecamatan Wanareja Kabupaten Cilacap yang berjumlah 35 orang. Untuk mengetahui peranan wanita dalam usahatani padi sawah dan tingkat penerapan teknologi PTT di Desa Wanareja Kecamatan Wanareja Kabupaten Cilacap dibagi kedalam 3 kategori yaitu tinggi, sedang dan rendah serta dilakukan analisis secara deskriptif. Sedangkan untuk menentukan interval masing-masing kategori dilakukan perhitungan menurut Sudjana (2003). Untuk menguji hipotesis secara parsial digunakan rumus koefisien Korelasi Rank Spearman. Hasil dari penelitian ini adalah: 1)Tingkat peranan wanita tani dalam budidaya padi sawah termasuk dalam kategori sedang. Sedangkan dalam setiap kegiatan budidaya padi sawah yaitu pada kegiatan penanaman, panen dan pasca panen termasuk kategori tinggi, pada kegiatan penggunaan benih dan bibit, pengolahan tanah dan pemeliharaan termasuk dalam kategori tinggi dan sedang. 2)Tingkat penerapan teknologi PTT pada usahatani padi sawah yang dijalankannya termasuk dalam kategori sedang. Sedangkan untuk masing-masing komponen teknologi yaitu penggunaan benih dan bibit termasuk kategori tinggi dan sedang, pada komponen penanaman, pemupukan dan pemeliharaan termasuk dalam kategori sedang. Tingkat penerapan teknologi PTT pada komponen panen dan pasca panen termasuk dalam kategori rendah. 3)Terdapat hubungan positif yang nyata antara peranan wanita dalam budidaya padi sawah dengan penerapan teknologi Pengelolaan Tanaman Terpadu (PTT).
\end{abstract}

\section{Kata kunci : Peranan Wanita, Budidaya Padi Sawah, PTT}

\section{PENDAHULUAN}

Pertumbuhan jumlah penduduk di Indonesia yang cepat berakibat pada peningkatan kebutuhan pangan yang juga terus bertambah, khususnya kebutuhan bahan pangan beras yang merupakan makanan pokok mayoritas orang Indonesia. Telah banyak upaya yang dilakukan pemerintah dalam rangka peningkatan produksi padi di Indonesia agar dapat memenuhi kebutuhan beras nasional dan pencapaian swasembada beras (Kementan, 2010).

Untuk mempercepat alih teknologi Pengelolaan Tanaman Terpadu (PTT) kepada petani, maka pemerintah mengadakan kegiatan Sekolah Lapang Pengelolaan Tanaman Terpadu (SL-PTT) yang dilaksanakan di tingkat kelompok tani. SL-PTT merupakan bentuk sekolah yang seluruh proses belajar mengajarnya dilakukan di lapangan yang dilaksanakan di lahan petani peserta SL-PTT. Pendekatan PTT bersifat partisipatif yang sangat memperhatikan penerapan teknologi dengan kesesuaian kebiasaan masyarakat setempat (Suryana, 2007). Kegiatan SL-PTT merupakan pengembangan dari kegiatan Sekolah Lapang Pengendalian Hama Terpadu (SLPHT). Kegiatan SL-PHT telah menunjukkan bahwa dengan belajar langsung di lahan dan melakukannya sendiri maka petani akan lebih cepat menerima dan melaksanakan teknologi baru. Hal ini sesuai dengan pernyataan Suryana (2007) bahwa faktor pengetahuan dan pengalaman dapat diperoleh sambil melakukan kerja.

Kegiatan penyebarluasan teknologi baru melalui kegiatan SL-PTT sangat dibutuhkan di Kabupaten Cilacap dalam rangka peningkatan produksi padi untuk mendukung tercapainya program P2BN dan swasembada beras.Usahatani 
padi sawah di Kabupaten Cilacap tersebar di 24 kecamatan yang diusahakan pada lahan seluas 69.963 hektar, dengan produksi mencapai 766.428 ton dan produktivitasnya 5,98 ton per hektar

Kecamatan Wanareja merupakan salah satu sentra produksi padi sawah di Kabupaten Cilacap, dengan luas lahan 4.229 hektar, produksinya mencapai 50.630 ton dan produktivitasnya 6,05 ton per hektar. Di Kecamatan Wanareja, Desa Wanareja merupakan desa yang mendapatkan program pembuatan demplot PTT terbanyak pada tahun 2013 yaitu dilaksanakan di 7 kelompok tani pada lahan sawah seluas 175 hektar.

Peserta SL-PTT yaitu petani anggota kelompok tani baik laki-laki maupun perempuan. Kondisi yang ada saat ini, petani perempuan jarang dilibatkan dalam kegiatan penyuluhan, sehingga petani perempuan sulit mengakses informasi dan mendapatkan manfaat dari pembangunan di bidang pertanian. Kebijakan pemerintah seringkali juga tidak berpihak kepada petani perempuan. Hal ini berkaitan dengan kualitas SDM, dimana pada umumnya tingkat. pendidikan perempuan lebih rendah sehingg2. sulit mengakses teknologi (Novia, 2006).

Sedangkan menurut Priyadi (2005) dalam Novia (2006) dalam pelaksanaan usahatani padi sawah mulai tahapan pengolahan lahan, penanaman hingga pemetikan hasil memungkinkan terserapnya tenaga kerja laki-laki dan perempuan. Adanya kultur masyarakat yang menempatkan perempuan dengan perspektif tertentu mengakibatkan terjadinya bias gender dalam kegiatan usahatani padi. Pengolahan lahan pertanian didominasi hanya tenaga kerja lakilaki, begitu juga untuk kegiatan pemupukan melibatkan tenaga kerja laki-laki. Keadaan ini didasarkan pada pemahaman atas tenaga kerja laki-laki yang lebih kuat, sehingga sangat tepat untuk keperluan mencangkul ataupun mengoperasikan traktor. Sedangkan peranan wanita dalam usahatani padi diantaranya dalam kegiatan penanaman, pemupukan, penyiangan, pengairan, pengendalian hama dan penyakit, panen dan pasca panen.

Walaupun peranan wanita dalam usahatani padi sawah hanya sebatas pada pekerjaan yang tidak memerlukan tenaga yang kuat seperti laki laki, namun dalam penerapan teknologi baru pada usahatani padi sawah yang akan diterapkan wanita mempunyai peranan yang penting. Hal ini karena apabila ada teknologi baru yang diketahui oleh laki-laki sebagai kepala keluarga yang akan diterapkan dalam usahataninya mereka akan meminta pendapat wanita tani terlebih dahulu (Lesmana, 2005).

Berdasarkan uraian diatas maka penelitian ini dilakukan untuk mengetahui : 1)Peranan wanita tani dalam usahatani padi sawah di Desa Wanareja Kecamatan Wanareja. 2)Penerapan teknologi Pengelolaan Tanaman Terpadu (PTT) padi sawah di Desa Wanareja Kecamatan Wanareja. 3)Hubungan antara peranan wanita dalam budidaya padi sawah dengan penerapan teknologi Pengelolaan Tanaman Terpadu (PTT) secara parsial.

\section{METODE PENELITIAN \\ Jenis Penelitian}

Jenis penelitian yang digunakan adalah penelitian survai. Menurut Sugiyono (2003) penelitian survai adalah penelitian yang dilakukan pada populasi besar maupun kecil untuk mengetahui kejadian- kejadian relatif, distribusi dan hubungan antar variabel, sosiologis maupun psikologis.

\section{Operasionalisasi Variabel}

Variabel yang diamati dalam penelitian ini dioperasionalisasikan sebagai berikut:

1. Peranan wanita dalam budidaya padi sawah, adalah peranan wanita dalam kegiatan yang dilakukan pada budidaya padi sawah yang meliputi :

a. Penggunaan benih

Dioperasionalisasikan sebagai peranan wanita dalam kegiatan pemilihan varietas yang akan ditanam dan perlakuan benih dalam budidaya padi sawah. Pengukuran dilakukan dengan sistem skoring.

b. Penanaman

Dioperasionalisasikan sebagai peranan wanita dalam kegiatan penanaman dalam budidaya padi sawah. Pengukuran dilakukan dengan sistem skoring.

c. Pemeliharaan

Dioperasionalisasikan sebagai peranan wanita dalam kegiatan pemeliharaan pada budidaya padi sawah yang meliputi kegiatan pemupukan, penyiangan, pengendalian hama dan penyakit. Pengukuran dilakukan dengan sistem skoring.

d. Panen dan Pasca Panen

Dioperasionalisasikan sebagai peranan wanita dalam kegiatan pemanenan padi 
sawah dan proses pengeringan. Pengukuran dilakukan dengan sistem skoring.

2. Penerapan teknologi PTT, adalah teknologi baru yang dianjurkan oleh pemerintah dalam melakukan budidaya padi sawah yang terdiri dari unsur-unsur sebagai berikut:

a. Penggunaan benih dan bibit yang dianjurkan dalam teknologi PTT padi sawah meliputi penggunaan varietaß unggul baru, perlakuan benih, dart. penggunaan bibit. Pengukuran dilakukan dengan sistem skoring.

b. Penanaman sesuai dengan yang dianjurkan dalam teknologi PTT padi sawah meliputi cara tanam dan pengaturan jarak tanam. Pengukuran dilakukan dengan sistem skoring.

c. Pemupukan sesuai dengan yang dianjurkan dalam teknologi PTT padi sawah meliputi penggunaan pupuk organik dan pemupukan berdasarkan BWD dan PUTS. Pengukuran dilakukan dengan sistem skoring.

d. Pemeliharaan sesuai dengan yang dianjurkan dalam teknologi PTT padi sawah meliputi penyiangan, pengairan dan Pengendalian Hama Terpadu (PHT). Pengukuran dilakukan dengan sistem skoring.

e. Panen dan pasca panen sesuai dengan yang dianjurkan dalam teknologi PTT padi sawah meliputi panen dan pengeringan. Pengukuran dilakukan dengan sistem skoring.

\section{Teknik Pengumpulan Data}

Data yang digunakan dalam penelitian ini meliputi data primer dan data sekunder. Data primer diperoleh dari wanita tani yang melakukan usahatani padi sawah sebagai responden, sedangkan data sekunder diperoleh dari Dinas yang terkait dengan penelitian ini dan dari studi kepustakaan.

\section{Teknik Penarikan Sampel}

Desa Wanareja dipilih secara sengaja (purposive sampling), dengan pertimbangan bahwa desa yang mendapatkan demplot SLPTT terbanyak di Kecamatan Wanareja. Menurut Sugiyono (2003) purposive sampling adalah teknik penentuan sampel dengan pertimbangan tertentu.

Teknik penarikan sampel menggunakan metodesensusterhadap seluruh wanita tani yang melakukan usahatani padi dan pernah mengikuti kegiatan SLPTT Padi Sawah di Desa Wanareja yaitu sebanyak 35 orang. Menurut Arikunto (2010) sensus adalah mengambil semua anggota populasi sebagai sampel penelitian.

\section{Rancangan Analisis Data dan Uji Hipotesis}

Untuk mengetahui peranan wanita dalam usahatani padi sawah dan tingkat penerapan teknologi PTT di Desa Wanareja Kecamatan Wanareja Kabupaten Cilacap dibagi ke dalam 3 kategori yaitu tinggi, sedang dan rendah serta dilakukan analisis secara deskriptif. Sedangkan untuk menentukan interval masing-masing kategori dilakukan perhitungan menurut Sudjana (2003) sebagai berikut:

$$
\begin{aligned}
& \text { Panjang Kelas Interval }=\frac{\text { Rentang }}{\text { Banyak kelas }} \\
& \text { Keterangan : } \\
& \text { Rentang = Nilai maksimal }- \text { Nilai minimal } \\
& \text { Banyak kelas = jumlah kategori }
\end{aligned}
$$

Nilai maksimal merupakan nilai tertinggi dari masing-masing variabel dan indikatornya, sedangkan nilai minimal merupakan nilai terendah dari masing-masing variabel dan indikatornya yang didapat dari jawaban pertanyaan-pertanyaan yang diajukan.

Dari rumusan tersebut maka dapat ditentukan kriteria sebagai berikut:

a. Peranan wanita dalam budidaya padi sawah

1) Peranan wanita rendah : $20,00 \leq Q \leq 46,67$

2) Peranan wanita sedang : $46,67<Q \leq 73,34$

3) Peranan wanita tinggi : $73,34<Q \leq 100,00$

b. Tingkat penerapan teknologi PTT

1) Tingkat penerapan teknologi PTT rendah : $13,00 \leq \mathrm{Q} \leq 30,33$

2) Tingkat penerapan teknologi PTT sedang : $30,33<\mathrm{Q} \leq 47,66$

3) Tingkat penerapan teknologi PTT tinggi : $47,66<\mathrm{Q} \leq 65,00$

Keterangan :

$\mathrm{Q}=$ Jumlah nilai yang dicapai 
Untuk menguji hipotesis secara parsial digunakan rumus koefisien Korelasi Rank Spearman sebagai berikut:

$$
r^{s}=1-\frac{6 \sum_{i=1}^{N} d_{i}^{2}}{N^{3}-N}
$$

Keterangan :

$r^{s}=$ Korelasi Rank Spearman

$d_{1}^{2}=$ Perbedaan antara Jumlah Rank $\mathrm{X}$

(Peranan Wanita Tani) dan Rank Y

(Penerapan Teknologi PTT)

$\mathrm{N}=$ Jumlah Responden

Untuk pengujian hipotesis digunakan uji $\mathrm{t}$ dengan rumus sebagai berikut:

$$
t=r s \sqrt{\frac{N-2}{1-(r s)^{2}}}
$$

Keterangan :

$\mathrm{t}=\mathrm{t}$ hitung

$\mathrm{N}=$ Jumlah data observasi

$\mathrm{rs}=$ korelasi rank spearman

Taraf kepercayaan yang digunakan dalam penelitian ini adalah $95 \%$

Jika thitung > ttabel 0,05 maka Hi diterima dan Ho ditolak, artinya peranan wanita dalam usahatani padi sawah mempunyai hubungan positif yang nyata dengan penerapan teknologi PTT di Desa Wanareja Kecamatan Wanareja

Jika t hitung< $t$ tabel 0,05 maka Hi ditolak dan Ho diterima, artinya peranan wanita dalam usahatani padi sawah tidak mempunyai hubungan nyata dengan penerapan teknologi PTT di Desa Wanareja Kecamatan Wanareja.

Menurut Sugiyono (2003), taksiran nilai korelasi yang digunakan adalah antara 0 sampai 1 yang terbagi atas beberapa kategori, yaitu korelasi sangat rendah, korelasi rendah, korelasi agak rendah, korelasi cukup dan korelasi tinggi.

\section{HASIL DAN PEMBAHASAN Identitas Responden}

Jumlah responden yang terlibat dalam penelitian ini sebanyak 35 orang wanita tani yang pernah mengikuti kegiatan SL-PTT Padi Sawah di Desa Wanareja Kabupaten Cilacap.

\section{Umur Responden}

Responden yang diteliti memiliki umur antara 31 tahun sampai 60 tahun. seluruh responden berada pada usia produktif karena berumur antara 32 sampai dengan 60 tahun. Menurut Ritonga (2003) bahwa penduduk usia produktif adalah penduduk berumur 15 sampai 64 tahun.

\section{Tingkat Pendidikan}

Sebagian besar petani responden yaitu sebanyak 17 orang atau 48,57persen mengikuti jenjang pendidikan formal sampai tingkat SD. Terbatasnya tingkat pendidikan formal yang diikuti wanita tani responden ini diantaranya disebabkan oleh keterbatasan ekonomi keluarga tani.

\section{Kepemilikan Lahan}

Sebagian besar responden yaitu sebanyak 32 orang atau 91,43 persen luas lahannya kurang dari 0,5 hektar dan termasuk ke dalam kategori skala usaha sempit. Hal tersebut sejalan dengan pendapat Soekartawi (2002) yang menyatakan bahwa skala usahatani berdasarkan luas lahan garapan dapat dibagi ke dalam tiga golongan yaitu skala luas jika lahan garapan lebih dari 1 hektar, skala sedang antara 0,5 sampai 1 hektar, dan skala sempit jika luas lahan garapan kurang dari 0,5 hektar

\section{Pengalaman Usaha Tani}

Sebagian besar responden pengalaman usahataninya antara 5-13 tahun yaitu sebanyak 14 orang atau 40 persen dari seluruh orang responden yang berjumlah 35 orang.

\section{Tanggungan Keluarga}

Sebagian besar responden mempunyai tanggungan keluarga kurang dari 4 orang yaitu sebanyak 33 orang atau 94,28 persen. Hal tersebut menunjukkan bahwa program Keluarga Berencana di Desa Wanareja cukup berhasil.

\section{Tingkat Peranan Wanita Tani Dalam Budidaya Padi Sawah}

Sebagian besar responden yaitu 17 orang atau 48,57 persen peranannya dalam budidaya padi sawah termasuk ke dalam kategori sedang. Hal tersebut karena hampir semua kegiatan dalam budidaya padi sawah dilakukan bersama dengan laki-laki, dan apabila suaminya bekerja pada orang lain maka wanita mengerjakan pekerjaan ringan di sawahnya sendiri. 
Sedangkan peranan responden dalam setiap komponen teknologi pada budidaya padi sawah dapat dijelaskan sebagai berikut:

\section{1) Tingkat Peranan Wanita dalam Penggunaan Bibit dan Benih}

Sebagian besar responden termasuk dalam kategori tinggi dan sedang yaitu sebanyak 30 orang atau 85,72 persen $(15$ orang tinggi dan 15 orang sedang). Dalam kegiatan pembibitan wanita lebih banyak terlibat dalam kegiatan seleksi benih karena kegiatan ini tidak terlalu berat dan memerlukan ketelatenan.

2) Peranan Wanita dalam Pengolahan Tanah Pada Budidaya Padi Sawah

Pada kegiatan pengolahan tanah sebagian besar responden yaitu sebanyak 30 orang atau 85,72 persen termasuk kategori tinggi dan sedang ( 15 orang tinggi dan 15 orang sedang ). Saat pengolahan lahan wanita tidak terlibat langsung dalam kegiatan dilapangan karena pengolahan lahan termasuk pekerjaan yang berat dan biasanya dilakukan dengan traktor. Keterlibatan wanita hanya pada penentuan cara pengolahan dan waktu pengolahan karena wanita berperan dalam menyediakan makanan untuk para pekerja.

3) Tingkat Peranan Wanita dalam Penanaman

Sebagian besar responden yaitu sebanyak 25 orang atau 71,43 persen dari seluruh responden yang berjumlah 35 orang pada kegiatan penanaman termasuk kategori tinggi. Hal ini karena di Desa Wanareja dalam kegiatan penanaman padi sawah semua dilakukan oleh wanita tani, kaum pria hanya terlibat dalam kegiatan pembuatan jarak tanam.

4) Peranan Wanita dalam Pemeliharaan Pada Budidaya Padi Sawah

Sebagian besar responden yaitu sebanyak 26 orang atau 74,28 persen dari seluruh responden yang berjumlah 35 orang termasuk kategori tinggi dan sedang ( 13 orang tinggi dan 13 orang sedang). Wanita biasanya berperan dalam kegiatan pemupukan dan penyiangan, untuk pengairan dan pengendalian hama biasanya dilakukan oleh kaum pria, tetapi apabila kaum pria mempunyai pekerjaan lain biasanya kegiatan ini dilakukan oleh wanita tani.

5) Tingkat Peranan Wanita dalam Panen dan Pasca Panen
Sebagian besar responden yaitu sebanyak 22 orang atau 62,86 persen dari seluruh responden yang berjumlah 35 orang termasuk kategori tinggi. Hal ini karena dalam kegiatan panen dan pasca panen padi wanita tani berperan pada proses pengaritan, perontokan dan penjemuran. Pria berperan dalam proses pengangkutan dan membantu dalam proses perontokan. Saat penjemuran dilakukan bersama-sama antara pria dan wanita.

\section{Tingkat Penerapan Teknologi PTT}

Sebagian besar responden yaitu sebanyak 20 orang atau 57,14 persen tingkat penerapan teknologi PTT pada usahatani sawah yang dijalankannya termasuk ke dalam kategori sedang. Hal tersebut karena ada beberapa komponen teknologi yang sulit diterapkan di lahan usahatani dan ada beberapa kebiasaan petani yang sulit untuk dirubah.

Sedangkan tingkat penerapan untuk masingmasing komponen teknologi dapat dijelaskan sebagai berikut:

\section{1) Tingkat Penerapan Teknologi Penggunaan Benih dan Bibit}

Sebagian besar responden yaitu sebanyak 34 orang atau 62,86 persen tingkat penerapan teknologi penggunaan benih dan bibit yang dijalankan termasuk dalam kategori tinggi dan sedang (17 orang tinggi dan 17 orang sedang). Hal tersebut karena petani kesulitan menerapkan penggunan bibit muda karena lahan usahataninya merupakan lahan yang rawan hama keong mas.

2) Tingkat Penerapan Teknologi Penanaman Sebagian besar responden yaitu sebanyak 19 orang atau 54,29 persen tingkat penerapan teknologi penanaman yang dijalankan termasuk dalam kategori sedang. Pada kegiatan usahatani semua responden sudah menerapkanpengaturan jarak tanam sis tem tegel, sedangkan sistem jajar legowo baru sebagian petani yang menerapkan.

3) Tingkat Penerapan Teknologi Pemupukan Sebagian besar responden yaitu sebanyak 20 orang atau 57,14 persen tingkat penerapan teknologi pemupukan yang dijalankannya termasuk dalam kategori sedang. Hal ini karena sebagian besar responden sudah menggunakan pupuk berimbang, pupuk yang biasa digunakan yaitu pupuk majemuk (NPK) dengan penambahan Urea. Sedangkan untuk 
penggunaan pupuk organik baru beberapa petani yang menerapkan, dan penggunaan BWD dan PUTS sulit diterapkan karena keterbatasan alat.

\section{4) Tingkat Penerapan Teknologi \\ Pemeliharaan}

Sebagian besar responden yaitu sebanyak 22 orang atau 62,68 persen dari jumlah responden sebanyak 35 orang tingkat penerapan teknologi pemeliharaan yang dijalankannya termasuk dalam kategori sedang. Komponen teknologi pengairan berselang dan pengendalian gulma secara terpadu sudah diterapkan oleh petani kecuali pada lahan tadah hujan, sedangkan dalam pengendalian hama dan penyakit baru sebagian yang kecil yang melakukan secara terpadu.

5) Tingkat Penerapan Teknologi Panen Dan

\section{Pasca Panen}

Sebagian besar responden yaitu sebanyak 21 orang atau 60 persen tingkat penerapan teknologi panen dan pasca panen yang dijalankannya termasuk dalam kategori rendah. Hal tersebut karena dalam proses panen dan pasca panen hanya beberapa responden yang menggunakan alat perontok bermesin karena proses panen masih menggunakan sistem bawon.Penggunaan lantai jemur pada proses pengeringan hanya dilakukan oleh petani yang mempunyai lahan luas. Untuk petani yang mempunyai lahan sempit proses penjemuran menggunakan terpal.

\section{Hubungan Peranan Wanita Tani Dalam Budidaya Padi Sawah dengan Penerapan Teknologi PTT}

Berdasarkan hasil penelitian diketahui bahwa rata-rata peranan wanita dalam budidaya padi sawah dari 35 orang responden adalah sebesar 68,63 dengan standar deviasi 13,44. Sedangkan rata-rata penerapan teknologi Pengelolaan Tanaman Terpadu (PTT) dari 35 orang responden adalah sebesar 40,63 dengan standar deviasi 8,09

1) Hasil analisis statistik menunjukkan bahwa nilai koefisien korelasi positif sebesar 0,411. Hal tersebut menunjukkan bahwa tingkat keeratan hubungan antara peranan wanita dalam budidaya padi sawah dengan penerapan teknologi Pengelolan Tanaman Terpadu (PTT) termasuk kategori agak rendah.
2) Setelah dilakukan pengujian statistik diketahui bahwa terdapat hubungan positif yang nyata antara hubungan peranan wanita dalam budidaya padi sawah dengan penerapan teknologi Pengelolan Tanaman Terpadu (PTT), karena $\mathrm{t}$ hitung $>\mathrm{t}$ tabel 0,05.Sifat korelasi positif menunjukkan semakin tinggi peranan wanita dalam budidaya padi sawah semakin tinggi pula penerapan teknologi PTT padi sawah atau sebaliknya semakin rendah peranan wanita dalam budidaya padi sawah semakin rendah pula penerapan teknologi PTT padi sawah. Hal tersebut mengindikasikan bahwa dalam budidaya padi sawah wanita memegang peranan penting dalam pengadopsian teknologi Pengelolaan Tanaman Terpadu (PTT).

\section{KESIMPULAN DAN SARAN \\ Kesimpulan}

Setelah dilakukan penelitian dan pembahasan maka diambil kesimpulan sebagai berikut:

1. Tingkat peranan wanita tani dalam budidaya padi sawah termasuk dalam kategori sedang. Sedangkan dalam setiap kegiatan budidaya padi sawah yaitu pada kegiatan penanaman, panen dan pasca panen termasuk kategori tinggi, pada kegiatan penggunaan benih dan bibit, pengolahan tanah dan pemeliharaan termasuk dalam kategori tinggi dan sedang.

2. Tingkat penerapan teknologi PTT pada usahatani padi sawah yang dijalankannya termasuk dalam kategori sedang. Sedangkan untuk masing-masing komponen teknologi yaitu penggunaan benih dan bibit termasuk kategori tinggi dan sedang, pada komponen penanaman, pemupukan dan pemeliharaan termasuk dalam kategori sedang. Tingkat penerapan teknologi PTT pada komponen panen dan pasca panen termasuk dalam kategori rendah.

3. Terdapat hubungan positif yang nyata antara peranan wanita dalam budidaya padi sawah dengan penerapan teknologi Pengelolaan Tanaman Terpadu (PTT) .

\section{Saran}

Berdasarkan kesimpulan di atas, maka saran yang dapat diberikan yaitu:

1. Wanita tani sebaiknya turut aktif dalam kegiatan budidaya padi sawah, walaupun tidak terlibat langsung dalam kegiatan dilapangan tetapi ikut berperan aktif dalam 
pengambilan keputusan penerapan teknologi baru dan mengetahui serta menguasai teknologi-teknologi baru dalam dunia pertanian khususnya padi sawah.

2. Pemerintah sebaiknya dalam proses alih teknologi ke petani, peran wanita tani lebih ditingkatkan. Dalam kegiatan penyuluhan dan pelatihan-pelatihan pesertanya tidak hanya kaum pria saja tetapi juga melibatkan wanita tani, karena ternyata wanita juga berperan dalam proses penerapan teknologi baru.

\section{DAFTAR PUSTAKA}

Agri Aksi Kanisius, 2006 . Budidaya Tanaman Padi. Aneka Ilmu. Bandung.

Badan Pelaksana Penyuluhan dan Ketahanan Pangan. 2013. Program Penyuluhan Kabupaten Cilacap. Cilacap

Desa Wanareja. 2014. Profil Desa Wanareja. Cilacap

Ekaningtias,2010. Petunjuk TeknisPTT Pengelolaan Tanaman Terpadu Padi Sawah. Badan Penelitian Dan Pengembangan Pertanian. Balai Pengkajian Teknologi Pertanian Jawa Tengah. Semarang.

Herawati, W.D, 2012. Budidaya Padi. Javalitera. Yogyakarta.

Iskandar dan Ishak, 2009. Petunjuk Teknis PTT Padi Sawah. Dinas Pertanian dan Peternakan Kabupaten Cilacap. Cilacap.

Kementan, 2010. Pilihan Teknologi Padi. Tabloid Sinar Tani. Jakarta

Lesmana, D. 2005. Peranan Wanita Dalam Pengambilan Keputusan Penerapan Teknologi Pada Usaha Tani Salak. Universitas Mulawarman. Samarinda.

Novia, D. 2006. Marginalisasi Perempuan dalam Pembangunan Pertanian.Universitas Brawijaya. Malang.

Pitojo, Setijo. Ir. 2003. Bertanam Padi Sawah Tabela. Penebar Swadaya. Jakarta.

Priyadi, U. 2005. Tingkat Kesetaraan Gender Pada Usaha Tani Padi di Kecamatan Mlati Kabupaten Sleman. Sleman.

PusatPenelitiandanPengembangan Tanaman Pangan.1994. Peranan Wanita dalam Usahatani. Prosiding Lokakarya "Gender Analysis" dalam sistem usahatani. Bogor 1415 April 1992. Pusat Penelitian dan Pengembangan TanamanPangan.Bogor.
Sajogyo. 2003. Sosiologi Pedesaan Jilid 2. Gajah Mada Universiti Press. Yogyakarta

Soekartawi. 2002. Prinsip Dasar Managemen Pemasaran Hasil Hasil Pertanian, Teori dan Aplikasi. PT Raja Gravindo Persada. Jakarta.

Sugeng, H.R. 2002. Bercocok Tanaman Padi. Aneka Ilmu. Semarang.

Sugiyono, DR. 2003. Metode Penelitian Administrasi. Penerbit CV Alfabeta. Bandung.

Sugiyono, DR. 2013. Statistik Nonparametrik Untuk Penelitian. Penerbit CV Alfabeta. Bandung.

Suryana,2007. Petunjuk Pelaksanaan PTT Padi. BPTP Jawa Tengah. Semarang.

Yandianto, 2003. Bercocok Tanam Padi. M2S. Bandung 
Jurnal IImiah Mahasiswa AGROINFO GALUH

Volume 2 Nomor 3, Mei 2016

Halaman | 180 